\title{
The Protective Effect of Soybean and Thyme on Iron Deficiency Anemia in Rats
}

\author{
Nora M. El-Sheikh \\ Department of Biochemistry and Nutrition, Women's College, Ain Shams \\ University, Cairo, Egypt
}

\begin{abstract}
Objective: The present study is carried out to investigate the protective effect and antioxidant activity of soybean and thyme on iron deficiency anemia.

Material and Methods: Thirty five male albino rats were divided into five groups (7rats each). The first group fed on basal diet, iron sufficient (35 mg Fe / kg), and served as control. Rats of other groups (second - fifth) were induced anemic by placing them on diet containing $3 \mathrm{mg} \mathrm{Fe} / \mathrm{kg}$ for 21 days, then divided to four dietary groups. The second group (anemic) stayed on basal diet with Fe-deficiency. The third group fed on basal diet with sufficient iron in the form of ferrous sulphate. The fourth group fed modified basal diet free from iron and supplemented with soybean. The fifth group fed basal diet free from iron and supplemented with thyme. All three iron sources provide $35 \mathrm{mg}$ iron $/ \mathrm{kg}$ diet. At the end of experiment (49 days), rats were anesthetized, whole blood was used for determination of hemoglobin $(\mathrm{Hb})$, hematocrit $(\mathrm{HCt})$ and reduced glutathione $(\mathrm{GSH})$ levels. Serum was used for determination of iron and lipid profile as well as lipid peroxidation as malondialdehyde (MDA). The liver was used for determination of iron and copper concentrations.

Results: The present results indicated that Fe-deficiency caused many adverse effects reflected the significant decrease of $\mathrm{Hb}, \mathrm{HCt}$, serum iron, liver iron, GSH and high density lipoprotein-cholesterol (HDL-C). Fe-deficiency also caused significant increase in total iron binding capacity (TIBC), liver copper, MDA, triacylglycerols (TG) and total cholesterol (TC). In contrary, administration of ferrous sulphate $\left(\mathrm{FeSO}_{4}\right)$, soybean or thyme induced a significant increase of serum and liver iron profile.

Conclusion: Soybean and thyme could able to provide iron to correct dietary irondeficiency anemia and powerful antioxidant effect of soybean or thyme was reflected on marked decrease of MDA and increase of GSH and HDL-C.
\end{abstract}

Key words: iron deficiency anemia-soybean- thyme- lipid peroxidation.

\section{Introduction}

Dietary iron-deficiency is the most common nutritional problem world wide, affecting approximately two billion people, mostly infants, children and women of reproductive age ( Viteri, 1997).

Iron-deficiency anemia (IDA) effects on development and growth, resistance to infections and association with mortality of infants younger than 2 years, it is considered a major public health problem. Moreover, IDA has negative effects on work capacity and on motor and mental development in infants, children, adolescents, fertile women, pregnant and the elderly (Hass and Brownlie, 2001).

Secondary nutritional effects, such as changes in enzyme activity, hyperlipidemia, increased hepatic copper accumulation and impaired cellular growth are important in addition to the anemia (Cunnane and $\mathrm{Mc}$ Adoo, 1987).

In biological systems, the steady-state level of lipid peroxidation is often assessed by the measurement of lipid peroxidation breakdown products such as malondialdehyde (MDA) (Uehara et al., 1997).

There is controversy about the susceptibility of the cells to lipid peroxideation in IDA. Some investigators have claimed; there is no difference in lipid peroxidation among patients with IDA as compared with controls (Isler et al., 2002), but others have reported that among patients with IDA, oxidants are increased 
and antioxidants decreased (Aslan et al., 2006).

Several studies have shown that some traditional foods containing the fermented soybean consumed in Japan and China possessed antioxidant activities (Iwai et al., 2002 and Chen et al., 2005).

Thyme (Thymus vulgaris L.) is aromatic plant used as spice extensively to add distinctive aroma and flavor to food. Thyme possess various beneficial effects, e.g., antiseptic, antimicrobial, bactericidal, anthelmintic, and possess antioxidant properties and it has been suggested as a natural replacement for synthetic antioxidant (Rasooli et al., 2006). Thyme is an excellent source of iron, manganese and vitamin $\mathrm{K}$, it is also a very good source of calcium (Sasaki et al., 2005).

The aim of the present study was to examine the effect of soybean and thyme on iron bioavailability and their prevention of lipid peroxidation in iron-deficient anemic rats.

\section{Material And Methods}

\section{Material}

Ground soybean was obtained from Agriculture Research Center, Ministry of Agriculture. Thyme was brought from local market at Cairo and was homogenized to a fine powder.

\section{Animals, Diet and Study Design}

Thirty five male Sprague-Dawley albino rats weighing 95-105 g were obtained from animal house of El Salaam farm, Giza, Egypt. All rats recived basal diet prepared following the defined composition of the AIN-93G (Reeves et al., 1993) for one week before the starting of the experiment for adaptation and to ensure normal growth and behavior. The rats were randomly assigned to five groups ( 7 rats for each) and housed individually in screenbottomed, stainless steel cages in a temperature $\left(24 \pm 2^{\circ} \mathrm{C}\right)$ with a $12 \mathrm{~h}$ lightdark cycle. All rats had free access to drinking water and diets through the whole experimental period (7 weeks).

The first group was fed on basal diet with $\mathrm{Fe}$ sufficient (AIN- 93G) containing $35 \mathrm{mg} \mathrm{Fe} / \mathrm{kg}$ diet in the form of ferrous sulphate heptahydrate throughout the study and served as control group.

Iron deficiency was induced in the other four groups (groups 2-5) by placing them on iron deficient diet $(3 \mathrm{mg} \mathrm{Fe} / \mathrm{kg}$ diet) for 21 days. At the end of iron depletion period, blood was taken from the tail of controls and Fe-deficient groups, hemoglobin and hematocrit were analyzed. The different groups of depleted rats were divided to receive one of the following diets for another 28 days.

Second group rats stayed on $\mathrm{Fe}$ deficient diet [Fe-deficient group].

Third group rats fed on basal diet with sufficient iron $(35 \mathrm{mg} \mathrm{Fe} / \mathrm{kg}$ diet) in the form of ferrous sulphate heptahydrate [Fe-def. $\left.+\mathrm{FeSO}_{4}\right]$.

Fourth group rats fed on modified basal diet contain $50 \mathrm{~g}$ casein and free from fat and iron, supplemented with ground soybean $(435 \mathrm{~g} / \mathrm{kg}$ diet $)$ which provide 35 $\mathrm{mg}$ iron $/ \mathrm{kg}$ diet [Fe-def. + soybean]. However, rats of the fifth group fed on basal diet free from iron and supplemented with thyme $(30 \mathrm{~g} / \mathrm{kg}$ diet $)$ which also provide $35 \mathrm{mg}$ iron $/ \mathrm{kg}$ diet [Fe-def. + thyme].

Animals were weighed weekly and food consumption was determined. Following 7 weeks of dietary treatment, after 12 hours of food deprivation, the rats were anesthetized with diethyl ether and blood samples were collected from the portal vein. Portion was collected into heparinized tubes to determine hemoglobin, hematocrit and glutathione content. Another portion was collected into tubes without anticoagulant to obtain serum and stored at $-20^{\circ} \mathrm{C}$ until further analyses.

The livers of rats were immediately removed, perfused by cold $0.9 \%$ sodium chloride solution and blotted on filter paper, then weighted and kept frozen at $-20^{\circ} \mathrm{C}$.

\section{Biochemical Analyses}

Blood hemoglobin concentration $(\mathrm{Hb})$ was measured according to the method described by Wintrobe et al. (1968), packed red cell volumes, hematocrit, ( $\mathrm{HCt})$ were determined by centrifugation in a capillary tube system. Blood reduced glutathione content (GSH) was assayed according to the method described by Beutler et al. (1963). The 
method of Colenbrander and Vink (1970) was used for the determination of serum iron (SI) concentration and total ironbinding capacity (TIBC). Lipid peroxideation expressed as malondialdehyde (MDA) was measured according to the described procedure of Draper and Hadly (1990). Hepatic iron and copper levels were determined after liquid digestion of wet tissue by atomic absorption spectrophotometry as described by Murthy et al. (1973). Serum triacylglycerols (TG) were estimated by an enzymatic colorimetric method described by Fossati and Principe (1982). Serum total cholesterol (TC) was estimated by enzymatic colorimetric method with lipid clearing factor as published by Roeschlau et al. (1974). Serum HDL-C was determined according to the method described by Richmond (1973).

\section{Statistical Analysis}

Data were analyzed by SPSS statistical package version 9.0. All results are presented as mean \pm S.E. A one-way ANOVA was employed for comparison among the five groups. Post-hoc multiple comparison test of significant differences among groups were determined. A 5\% level of probability was used to define differences as significant (Bailey, 1995).

\section{Results}

At the end of 3 weeks of iron depletion, groups fed on the low-Fe diet exhibited Fe deficiency anemia. There was significant lowering $\mathrm{Hb}$ and $\mathrm{HCt}$ levels from control group. Administration of $\mathrm{Fe}$ treatment sources $\left(\mathrm{FeSO}_{4}\right.$, soybean and thyme) to deficient groups resulted in significantly higher levels of $\mathrm{Hb}$ and $\mathrm{HCt}$ compared to pre- treatment (at $21 \mathrm{~d}$ and 49 d) as shown in table (1).

Table (2) reveals that growth of animals fed the Fe-deficient diet was impaired, with a recorded average final body weight $166.43 \pm 4.04 \mathrm{~g}$ as compared with $235.86 \pm 8.72 \mathrm{~g}$ for those animals fed diet of adequate iron (control). Also there was significant decrease in food intake and feed efficiency ratio, while there was significant increase of hepatosomatic index for Fe-deficient rats as compared with controls. The administration of all three iron sources induced significantly increase of final body weight, food intake and feed efficiency ratio and induced significantly decrease of hepatosomatic index as compared to the Fe-deficient group.

Iron status of animals in each dietary group assessed by measuring $\mathrm{Hb}, \mathrm{HCt}$, SI, TIBC and liver iron are presented in table (3). After consuming the low Fe-diet for 49 $\mathrm{d}$, iron status parameters in the Fe-deficient group were dramatically different from those of the controls, $\mathrm{Hb}, \mathrm{HCt}$, SI and liver iron were low and TIBC increased markedly indicating that these animals were severely iron deficient. All the three iron sources resulted in significantly higher levels of $\mathrm{Hb}, \mathrm{HCt}$, serum and liver iron concentrations, and significantly lower in TIBC as compared to Fe-deficient group.

Table ( 3) shows also that there were significant differences in $\mathrm{Hb}, \mathrm{HCt}$, SI and TIBC in rats fed soybean or thyme as compared to rats fed $\mathrm{FeSO}_{4}$.

Mean liver copper concentration was significantly increased in Fe-deficient animals as compared to controls (figure 1). The treatment with $\mathrm{FeSO}_{4}$, soybean or thyme induced significantly decreased liver copper as compared with Fe-deficient rats. There was no significant difference between rats treatment with soybean or thyme as compared to rats treatment with $\mathrm{FeSO}_{4}$.

Table (4) shows that significant increment in MDA levels while significant decrement in GSH content were found in Fe-deficient group as compared to control group. All the three iron sources altered the previous results, i.e. there was significant decrease in MDA levels and increase in GSH content as compared to Fe-deficient rats. There was no significant difference in MDA levels and GSH content in rats supplemented with soybean or thyme as compared to those supplemented with $\mathrm{FeSO}_{4}$.

Serum TG and TC concentrations in rats fed the $\mathrm{Fe}$-deficient diet were significantly higher than in rats fed the $\mathrm{Fe}$ adequate diet. Mean serum HDL-C concentration was lower in rats fed the $\mathrm{Fe}$ deficient diet than in those fed Fe-adequate diet. The supplementation with the three iron sources resulted in decrease of TG and TC concentrations, while increase of HDL- 
$\mathrm{C}$ was recorded as compared with $\mathrm{Fe}$ deficient group. There was no significant difference in levels of serum lipid parameters between group supplemented with thyme and that supplemented with $\mathrm{FeSO}_{4}$ (Figure 2).

Table(1): Hemoglobin (Hb) and Hematocrit (HCt) for Control and Different Experimental Groups 1 .

\begin{tabular}{|l|c|c|c|c|}
\hline \multirow{2}{*}{ Parameter } & \multicolumn{2}{|c|}{ Hb (g/dl) } & \multicolumn{2}{c|}{ HCt (\%) } \\
\cline { 2 - 5 } Dietary group & $\begin{array}{c}\text { Pre-treatment } \\
(21 \text { day) }\end{array}$ & $\begin{array}{c}\text { Post-treatment } \\
(49 \text { day })\end{array}$ & $\begin{array}{c}\text { Pre-treatment } \\
(21 \text { day) }\end{array}$ & $\begin{array}{c}\text { Post-treatment } \\
(49 \text { day) }\end{array}$ \\
\hline Control & $14.16 \pm 0.28^{\mathrm{a}}$ & $14.44 \pm 0.34^{\mathrm{a}}$ & $43.11 \pm 0.21^{\mathrm{a}}$ & $45.90 \pm 0.27^{\mathrm{a}}$ \\
\hline Fe-deficient & $8.61 \pm 0.25^{\mathrm{b}}$ & $4.61 \pm 0.40^{\mathrm{c}}$ & $33.51 \pm 0.34^{\mathrm{d}}$ & $24.24 \pm 0.29^{\mathrm{c}}$ \\
\hline Fe-def. + FeSO ${ }_{4}$ & $8.70 \pm 0.28^{\mathrm{b}}$ & $13.89 \pm 0.31^{\mathrm{a}}$ & $32.22 \pm 0.46^{\mathrm{d}}$ & $46.14 \pm 0.67^{\mathrm{a}}$ \\
\hline Fe-def. + soybean & $8.63 \pm 0.24^{\mathrm{b}}$ & $12.00 \pm 0.21^{\mathrm{e}}$ & $31.69 \pm 0.33^{\mathrm{d}}$ & $43.38 \pm 0.50^{\mathrm{e}}$ \\
\hline Fe-def. + thyme & $8.55 \pm 0.36^{\mathrm{b}}$ & $12.49 \pm 0.18^{\mathrm{e}}$ & $32.39 \pm 0.38^{\mathrm{d}}$ & $41.96 \pm 0.41^{\mathrm{e}}$ \\
\hline
\end{tabular}

1 values are means \pm SE.

Within a row, values not sharing a superscript letters are significantly different $(\mathrm{P}<0.05)$.

Table (2): Final Body Weight, Food Intake, Feed Efficiency Ratio and Hepatosomatic Index for Control and Different Experimental Groups ${ }^{1}$.

\begin{tabular}{|c|c|c|c|c|}
\hline Dietary group & $\begin{array}{l}\text { Final body weight } \\
\text { (g) }\end{array}$ & $\begin{array}{l}\text { Food intake } \\
\text { (g) }\end{array}$ & $\begin{array}{c}\text { Feed efficiency } \\
\text { ratio }\end{array}$ & $\begin{array}{c}\text { Hepatosomatic } \\
\text { Index }(\mathrm{g} \%)\end{array}$ \\
\hline Control & $235.86 \pm 8.72^{\mathrm{a}}$ & $751.86 \pm 21.90^{\mathrm{a}}$ & $0.182 \pm 0.014^{\mathrm{a}}$ & $2.50 \pm 0.11^{\mathrm{a}}$ \\
\hline Fe-deficient & $166.43 \pm 4.04^{b}$ & $633.71 \pm 25.91^{b}$ & $0.106 \pm 0.006^{b}$ & $4.21 \pm 0.15^{b}$ \\
\hline Fe-def. + FeSO ${ }_{4}$ & $241.71 \pm 7.42^{\mathrm{a}}$ & $749.00 \pm 19.11^{\mathrm{a}}$ & $0.190 \pm 0.009^{\mathrm{a}}$ & $2.85 \pm 0.09^{\mathrm{a}}$ \\
\hline Fe-def. + soybean & $243.29+6.65^{a}$ & $750.29+22.24^{a}$ & $0.190+0.006^{a}$ & $2.47+0.14^{\mathrm{a}}$ \\
\hline Fe-def. + thyme & $189.29 \pm 3.06^{c}$ & $642.29 \pm 38.63^{b}$ & $0.140 \pm 0.004^{c}$ & $2.74 \pm 0.13^{\mathrm{a}}$ \\
\hline
\end{tabular}

1 values are means \pm SE.

Within a column, values not sharing a superscript letters are significantly different $(\mathrm{P}<0.05)$.

Table (3): Hemoglobin (Hb), Hematocrit (HCt), Serum Iron (SI), Total Iron-binding Capacity (TIBC) and Liver Iron for Control and Different Experimental Groups ${ }^{1}$.

\begin{tabular}{|l|c|c|c|c|c|}
\hline \multicolumn{1}{|c|}{ Parameters } & $\begin{array}{c}\text { Hb } \\
(\mathbf{g} / \mathbf{d l})\end{array}$ & $\begin{array}{c}\text { HCt } \\
(\boldsymbol{\%})\end{array}$ & $\begin{array}{c}\text { SI } \\
(\mu \mathrm{g} / \mathbf{d l})\end{array}$ & $\begin{array}{c}\text { TIBC } \\
(\mu \mathrm{g} / \mathbf{d l})\end{array}$ & $\begin{array}{c}\text { Liver iron } \\
(\mu \mathrm{g} / \mathbf{g})\end{array}$ \\
\hline Dietary group & $14.44 \pm 0.34^{\mathrm{a}}$ & $45.90 \pm 0.27^{\mathrm{a}}$ & $385.59 \pm 3.22^{\mathrm{a}}$ & $284.00 \pm 3.18^{\mathrm{a}}$ & $215.43 \pm 3.12^{\mathrm{a}}$ \\
\hline Control & $4.61 \pm 0.40^{\mathrm{b}}$ & $24.24 \pm 0.29^{\mathrm{b}}$ & $186.98 \pm 2.02^{\mathrm{b}}$ & $572.68 \pm 5.28^{\mathrm{b}}$ & $139.29 \pm 2.48^{\mathrm{b}}$ \\
\hline Fe-deficient & $13.89 \pm 0.31^{\mathrm{a}}$ & $46.14 \pm 0.67^{\mathrm{a}}$ & $372.37 \pm 5.40^{\mathrm{c}}$ & $289.36 \pm 3.37^{\mathrm{a}}$ & $203.00 \pm 2.99^{\mathrm{c}}$ \\
\hline Fe-def. + FeSO ${ }_{4}$ & $12.00 \pm 0.21^{\mathrm{c}}$ & $43.38 \pm 0.50^{\mathrm{c}}$ & $327.50 \pm 3.92^{\mathrm{d}}$ & $366.26 \pm 2.20^{\mathrm{c}}$ & $199.29 \pm 4.68^{\mathrm{c}}$ \\
\hline Fe-def. + thymean & $12.49 \pm 0.18^{\mathrm{c}}$ & $41.96 \pm 0.41^{\mathrm{c}}$ & $349.45 \pm 5.87^{\mathrm{e}}$ & $313.06 \pm 5.17^{\mathrm{d}}$ & $202.71 \pm 2.97^{\mathrm{c}}$ \\
\hline
\end{tabular}

1 values are means $+\mathrm{SE}$.

Within a column, values not sharing a superscript letters are significantly different $(\mathrm{P}<0.05)$. 
Table (4): Serum Malandialdehyde (MDA) and Blood Glutathione (GSH) for Control and Different Experimental Groups ${ }^{1}$.

\begin{tabular}{|l|c|c|}
\hline \multicolumn{1}{|c|}{ Parameters } & $\begin{array}{c}\text { MDA } \\
(\mu \mathrm{mol} / \mathbf{l})\end{array}$ & $\begin{array}{c}\text { GSH } \\
(\mathbf{m g} / \mathbf{d l})\end{array}$ \\
\hline Dietary group & $4.22 \pm 0.20^{\mathrm{a}}$ & $7.38 \pm 0.29^{\mathrm{a}}$ \\
\hline Fe-deficient & $6.20 \pm 0.17^{\mathrm{b}}$ & $4.47 \pm 0.34^{\mathrm{b}}$ \\
\hline Fe-def. + FeSO ${ }_{4}$ & $4.52 \pm 0.26^{\mathrm{a}}$ & $7.53 \pm 0.25^{\mathrm{a}}$ \\
\hline Fe-def. + soybean & $4.58 \pm 0.24^{\mathrm{a}}$ & $6.68 \pm 0.23^{\mathrm{a}}$ \\
\hline Fe-def. + thyme & $3.93 \pm 0.16^{\mathrm{a}}$ & $7.92 \pm 0.20^{\mathrm{a}}$ \\
\hline
\end{tabular}

1 values are means \pm SE.

Within a column, values not sharing a superscript letters are significantly different $(\mathrm{P}<0.05)$.

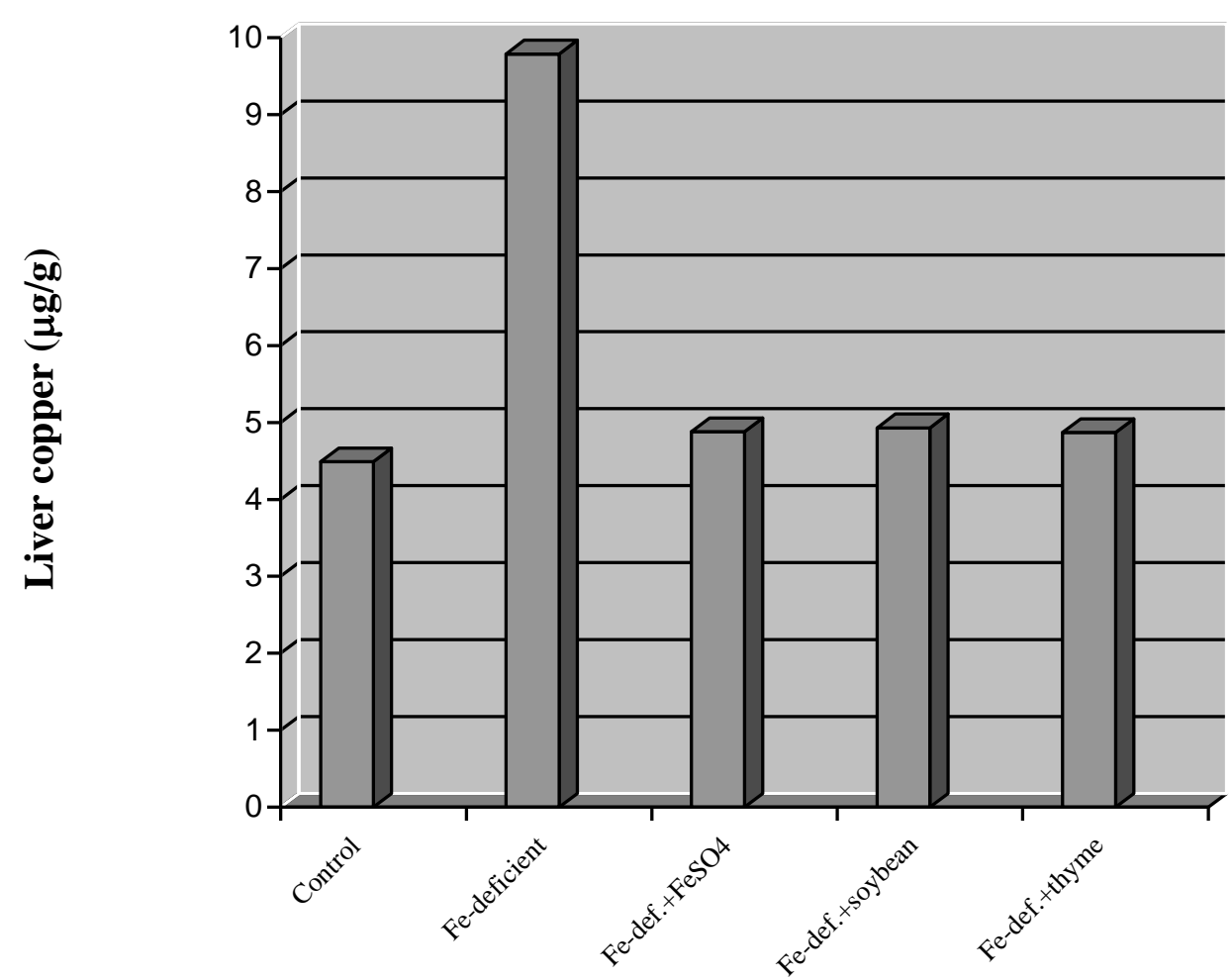

Groups

Figure (1): Liver copper for control and Different Experimental Groups. 


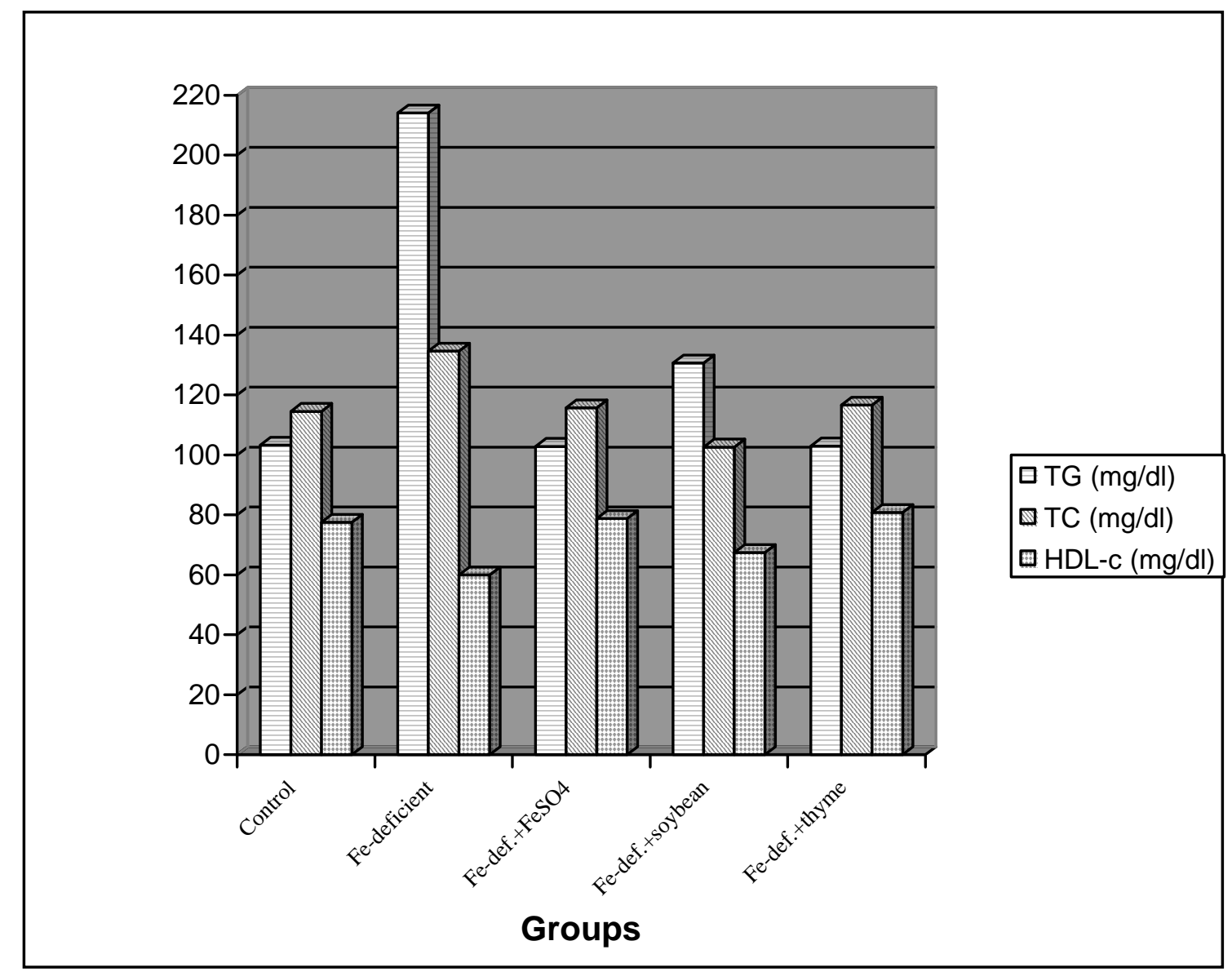

Figure (2): Serum lipids for control and Different Experimental Groups.

\section{Discussion}

The present study showed that the hemoglobin level of approximately $8.5 \mathrm{~g} / \mathrm{dl}$ confirmed that the diet period of 21 days with $3 \mathrm{mg} \mathrm{Fe} / \mathrm{kg}$ diet was sufficient to induce iron deficiency anemia, as reported in the literature (Srigiridhar and Nair, 2000).

The administration of $\mathrm{Fe}$ as $\mathrm{FeSO}_{4}$, soybean and thyme sources for a period of 28 days to Fe-depleted rats normalize the $\mathrm{Hb}$ and $\mathrm{HCt}$ levels. These results were in agreement with that of Beard et al. (1996) who tested the bioavailability of iron in ferritin and ferritin-containing seeds, by comparing the recovery from irondeficiency anemia among rats fed diets in which the only iron source was $\mathrm{FeSO}_{4}$, ferritin or baked soybean meal and found that all the three iron sources could treated anemia.

Iron deficient group in this study demonstrated the impaired growth that Lee et al. (1981) hypothesized to be the results of decreased food consumption rather to feed efficiency ratio often observed in animals fed an iron-deficient diet, this is in agreement with our results.

The degree of Fe deficiency produced by our Fe-restricted diet was severe enough to impair weight gain as found previously (Strube et al., 2002). This decrease in body weight observed in IDA rats may be due to lower plasma thyroid hormone levels (Beard et al., 1998).

Regarding hepatosomatic index, this study showed significant increase in $\mathrm{Fe}$ deficient group as compared to control group. The administration of iron sources $\left(\mathrm{FeSO}_{4}\right.$, soybean and thyme) induced significant increase in final body weight, food intake and feed efficiency ratio, but induced significant decreace in hepatosomatic index. In accordance with our results, Beard et al. (1996) found that iron-deficient animals that fed $\mathrm{FeSO}_{4}$, ferritin or baked soybean meal showed significant increase 
in body weight. Also, Kasaoka et al. (1997) reported that anemic rats fed with both unfermented soybean or tempeh (fermented soybean) have final body weight as rats that fed casein diet, so the treatment with soybean improve the decrease in body weight for Fe-deficient rats.

After $\mathrm{Fe}$ deprivation (feeding with 3 $\mathrm{mg} / \mathrm{kg}$ diet), hematologic parameters and iron status in the Fe-deficient group were dramatically different from those of the controls, with low mean blood $\mathrm{Hb}$ concentration. Similarly, HCt, SI, and Liver iron were low, whereas, TIBC increased markedly due to progressive $\mathrm{Fe}$ depletion from the body stores. All these findings were expected and consistent with induced severe IDA in rats. The similar results were demonstrated by other investigators (Uehara et al., 1997 and Diaz-Castro et al., 2008).

In the present study, the anemic groups that fed $\mathrm{FeSO}_{4}$, soybean or thyme as sources of iron showed a markedly increase of $\mathrm{Hb}, \mathrm{HCt}, \mathrm{SI}$ and liver iron with a markedly decrease of TIBC. These results were in agreement with the results of Beard et al. (1996), who mentioned that $\mathrm{Hb}$ and $\mathrm{HCt}$ of rats maintained on the iron-deficient diets were $41.4 \%$ and $35.5 \%$ of the control values, respectively. Organ iron was also replenished in rats fed diets with ferritin or baked soybean meal as the iron source. Soybean meal was effective in replenishing organ iron stores, the values were $185 \%$ and $313 \%$ of values for iron-deficient animals for spleen and liver, respectively, and concluded that iron in purified ferritin and iron in baked soybean meal were able to provide iron to correct dietary irondeficiency anemia.

Kasaoka et al. (1997) reported that there were no significant differences in $\mathrm{Hb}$, HCt, SI, UIBC and liver iron concentration between the unfermented and fermented soybean fed groups.

Regarding liver copper, the present study showed significant increase in $\mathrm{Fe}$ deficient group as compared to control group, this result was in line to the previously results reported by Sherman and Moran (1984) and Uehara et al. (1997).

In the present study, treatment with $\mathrm{FeSO}_{4}$, soybean or thyme induced significant decrease in liver copper as compared to Fe-deficient rats.

Contrary to the results of Rao and Jagadeesan (1996) who provide evidence that iron deficiency is protective against in vivo lipid peroxidation, the present study showed significant elevation in MDA levels in the serum of iron-deficient rats. This result is in harmony with that of Knutson et al. (2000). The present results exhibited that all three iron sources caused significant decrease in MDA levels. Seung et al. (2005) mentioned that thyme may protect the liver by preventing the increase of MDA because it scavenges the free radicals and this scavenging is one of the major antioxidant mechanisms to inhibit the chain reaction of lipid peroxidaion.

Concerning the effect of iron deficiency on glutathione content, decreased levels of GSH in the blood was observed, suggesting the increased utilization and subsequent depletion of this antioxidant to counter the increased level of lipid peroxidation. Previous studies have demonstrated increased lipid peroxides levels with parallel decrease in antioxidant defence system in erythrocytes of anemic patients, so the oxidative/antioxidative balance is shifted toward the oxidative side ( Kurtoglu et al., 2003).

The administration of the three iron sources resulted in an increase of GSH content as compared to Fe-deficient rats. The antioxidant effect of thyme reduce the use of GSH as an antioxidant and subsequently not depleted and its levels increased.

Several factors may contribute to elevated lipid peroxidation in Fe-deficient rats. First, it has been demonstrated repeatedly that iron-deficient rats rapidly accumulate copper in liver than those in normal rats. As with excess iron, copper can also catalyze lipid peroxidation (Uehara et al., 1997). Second, iron-deficient rats have been shown to accumulate triacylglycerols in liver and plasma. High concentration of TG provide more lipid substrate for lipid peroxidation, and this may have contributed to the high levels of MDA in the Fe-deficient rats (Masini et al., 1994).

Significant elevation of TG and TC 
levels were observed in Fe-deficient group as compared to normal control group. On the other hand, the levels of these parameters were decreased with administration of $\mathrm{FeSO}_{4}$, soybean or thyme. Furthermore, HDL-C was lower in Fe-deficient rats as compared to controls, the administration of iron sources induced an increase of HDL-C levels as compared to Fe-deficient rats. These results were in parallel with that of Uehara et al. (1997) who mentioned that iron deficiency causes an increase in TG, phospholipids, TC and LDL-C+VLDL-C levels while, HDL-C was decreased. Also, Knutson et al. (2000) found that IDA resulted in significant increase of plasma TG as compared to normal control, and the daily iron supplements induce a reduction of TG to near that in control group.

The mechanism of the hypertriglyceridemia is considered to be a rate of increased conversion from glucose, which was converted from accumulated lactic acid under the low oxygen concentration associated with iron-deficiency (Miller et al., 1990).

Several studies have suggested that the hypocholesterolemic effect of vegetable protein, particularly soybean protein, is largely attributable to higher fecal steroid excretion as a consequence of the reduction in intestinal absorption (Nagata et al., 1982 and Morita et al., 1997). Non-protein components (such as fiber, phytic acid, minirals and isoflavones) associated with soybean protein may also affect cholesterol metabolism (Potter, 1995). In compensation for the fecal loss of steroids, soybean protein may stimulate hepatic activities of hydroxy methylglutaryl CoA (HMG-CoA) reductase, the rate-limiting enzyme in the biosynthesis of cholesterol (Nagata et al., 1982), and cholesterol $7 \alpha$ - hydroxylase, the key enzyme that converts cholesterol to bile acid (Beymen, 1990).

In conclusion, the results indicate that soybean and thyme as iron sources improve iron status, similar to ferrous sulphate (the standard iron supplement) also they have a protective effect against iron-deficiency anemia, their effect may be due to both the inhibition of lipid peroxidation and the increase of antioxidant status. Whether soybean or thyme can be exploited for nutritional benefits remain to be explored and further studies demand.

\section{References}

1. Aslan M, Horoz M, Kocyigit A, Ozgonul S, Celik $H$ and Celik $M$ (2006): Lymphocyte DNA damage and oxidative stress in patients with iron deficiency anemia. Mutat. Res., 601: 144-149.

2. Bailey NT (1995): Statistical Methods in Biology $3^{\text {rd }}$. Cambridge Univ press, Cambridge.

3. Beard JL, Burton JW and Theil B (1996): Purified ferritin and soybean meal can be sources of iron for treating iron deficiency in rats. J. Nutr., 126: 154-160.

4. Beard JL, Brigham DE, Kelley SK and Green MH (1998): Plasma thyroid hormone kinetics are altered in irondeficient rats. J. Nutr., 128: 1401-1408.

5. Beutler E, Duran O and Kelly M (1963): Improved method for the determinaiton of blood glutathione, J.Lab. Clin. Med., 61(5): 882-888.

6. Beymen A (1990): Comparison of the mechanisms proposed to explain the hypocholesterolemic effect of soybean protein versus casein in experimental animals.J. Nutr. Sci. Vitaminol., 36: s 87- s 93.

7. Chen YC, Sugiyama Y, Abe N, KurutoNiwa R, Nozawa $R$ and Hirota A (2005): DPPH radical-scavenging compounds from dou-chi, a soybean fermented food. Biosci. Biotechnol. Biochem., 69: 999- 1006.

8. Colenbrander HJ and Vink CL (1970): Some aspects of the determination of serum iron and total iron-binding capacity with teepol. Clin. Chim. Acta., 28 (1): 175-184.

9. Cunnane SC and McAdoo KR (1987): Iron intake influences essential fatty acid and lipid composition of rat plasma and erythrocytes. J. Nutr., 117: 1514-1519.

10. Diaz-Castro J, Alferez MJ, Lopez-Aliaga I, Nestares T, Granados S, Barrionuevo $M$ and Campos MS (2008): Influence of nutritional iron deficiency anemia on DNA stability and lipid peroxidation in rats. Nutrition, 24: 1167-1173.

11. Draper HH and Hadley M (1990): Malondialdehyde determination as index of lipid peroxidation. Method in Enzymology, 86: 421-431.

12. Fossati $\mathbf{P}$ and Principe L (1982): Serum triglycerides determined colorimetrically with an enzyme that produces hydrogen peroxide. Clin. Chem., 28 (10): 2077: 2080.

13. Haas JD and Brownlie T (2001): Iron deficiency and reduced work capacity: a 
critical review of the research to determine a casual relationship. J. Nutr., 131: 676 s690s.

14. Isler M, Delibas N, Guclu M, Gultekin F, Sutcu $R$ and Bahceci $M$ (2002): Superoxide dismutase and glutathione peroxidas in erythrocytes of patients with iron deficiency anemia: effects of different treatment modalities. Coat. Med. J., 43: 1619.

15. Iwai K, Nakaya N, Kawaski $\mathbf{Y}$ and Matsue H (2002): Antioxidative functions of natto, a kined of fermented soybeans: effect on LDL-c oxidation and lipid metabolism in cholesterol-fed rats. J. Agric. Food Chem., 50: 3597-3601.

16. Kasaoka S, Astuti M, Uehara M, Suzuki $K$ and Goto S (1997): Effect of Indonesian fermented soybean temph on iron bioavailability and lipid peroxidation in anemic rats. J. Agric. Food chem., 45: 195198.

17. Knutson MD, Walter PB, Ames BN and Vitevi FE (2000): Both iron deficiency and daily iron supplements increased lipid peroxidation in rats. J. Nutr., 130: 621-625.

18. Kurtoglu E, Ugur A, Baltaci AK and Undar L (2003): Effect of supplementation on oxidative strees and antioxidant status in iron deficiency anemia. Biol. Trace Elem. Res., 96: 117-123.

19. Lee Y H, Layman DK and Bell RR (1981): Glutathione peroxidase activity in iron-deficient rats. J. Nutr., 111: 194-200.

20. Masini A, Trenti T, Caramazza I Prederi G, Gallesi D and Ceccarelli D (1994): Dietary iron deficiency in the rat. II. Recovery from energy metabolism derangement of the hepatic tissue by iron therapy. Biochim. Biophys. Acta., 1188: 53-57.

21. Miller PM, Buetnner GR and Aust SD (1990): Transition metals as catalysts of "autoxidation" reactions. Free Radic.Biol.Med.,8:95-108.

22. Morita T, Oh-hashi A, Takei K, Ikai M, Kasaoka $S$ and Kiriyama S (1997): Cholesterol-lowering effects of soybean, potato and rice proteins depend on their low methionine contents in rats fed a cholesterol-free purified diet. J. Nutr., 127: 470-477.

23. Murthy L, Menden EE, Eller PM and Petering HG (1973): Atomic absorption determination of zinc, copper, cadmium and lead in tissue solubilized by aqueous tetramethyammonium hydroxide. Anal. Biochem., 53: 365.

24. Nagata $\mathbf{Y}$, Ishiwaki $M$ and Sugano $M$ (1982): Studies on the mechanism of antihypercholesterolemic action of soy protein and soy protein-type amino acid mixtures in relation to the casein counterparts in rats. J. Nutr., 112: 16141625.

25. Potter SM (1995): Overview of proposed mechanisms for the hypocholesterolemic effect of Soy. J. Nutr., 125: 606 S- 611 S.

26. Rao J and Jagadeesan V (1996): Lipid peroxidation and activities of antioxidant enzymes in iron deficiency and effect of carcinogen feeding. Free Radic. Bio. Med., 21: 103-108.

27. Rasooli I, Rezaei MB and Allameh A (2006): Ultra structural studies on antimicrobial efficacy of thyme essential oils on listeria monocytogenes. International Journal Infectious Diseases, 10:236-241.

28. Reeves PG, Nielsen FH and Fahey GC (1993): AIN-93 purified diets for laboratory rodents: Final report of the American Institute of Nutrition Ad Hoc writing committee on the reformulation of the AIN-76 a rodent diet. J. Nutr., 123: 1939-1951.

29. Richmond N (1973): Preparation and properties of a cholesterol oxidase from Nocardia sp. and its application to the enzymatic assay of total cholesterol in serum. Clin. Chem., 19: 1350-1356.

30. Roeschlau P, Bernt $\mathbf{E}$ and Gruber W (1974): Enzymatic cholesterol test with lipid clearing factor (LCF). J. Clin. Chem. Clin. Biochem., 12: 403-408.

31. Sasaki K, Wada K, Tanaka Y, Yoshimura T and Matuoka K (2005): Thyme (Thmus Vulgaris L.) Leaves and its constituents increase the activities of xenobiotic-metabolizing enzyme in mouse liver. J. Med. Food, 8 (2): 184-189.

32. Seung L, Katumi U, Takayki $\mathbf{S}$ and Kwang-Geum L (2005): Identification of volatile components in basil and thyme leaves and their antioxidants properties. Food. Chem., 91 (1): 131-137.

33. Sherman AR and Moran PE (1984): Copper metabolism in iron-deficient maternal and neonatal rats. J. Nutr., 114: 298-306.

34. Srigiridhar $K$ and Nair $M$ (2000): Supplementation with $\alpha$-tochopherol or a combination of $\alpha$-tocopherol and ascorbic acid protects the gastrointestinal tract of iron-deficient rats against iron-induced oxidative damage during iron repletion. $\mathrm{Br}$. J. Nutr., 84: 165-173.

35. Strube YN, Beard JL and Ross AC (2002): Iron deficiency and marginal vitamin A deficiency affect growth 
hematological indices and the regulation of iron metabolism genes in rats. J. Nutr.,132: 3607-3615.

36. Uehara M, Chiba H, Mogi H, Suzuki K and Goto S (1997): Induction of increased phosphatidyl choline hydroperoxide by an iron-deficient diet in rats. J. Nutr. Biochem., 8: 385-391.
37. Viteri F E (1997): Iron supplementation for the control of iron deficiency populations at risk. Nutr. Rev., 55: 195-209.

38. Wintrobe M, Mollin D and Herbert V (1968): Anemias nutricionales. Organizatión Mundial de la Salud, Serie Informe Técnicos, 405:5-39.

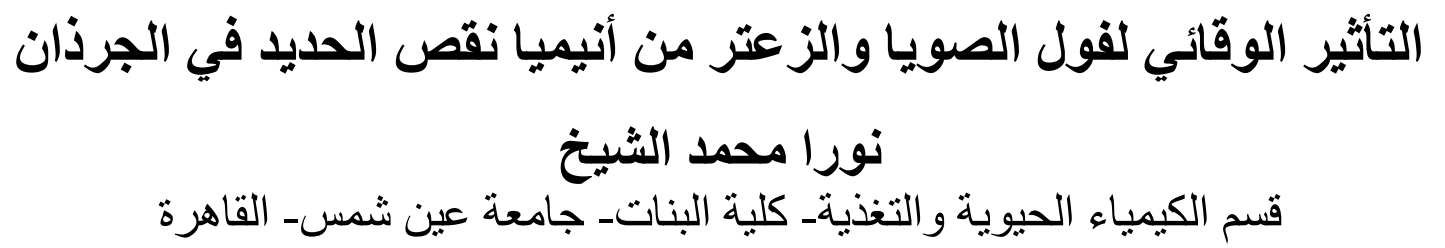




\section{Nora M. El-Sheikh}

جمهورية مصر العربية

الغرض من الدراسة: تم اجر اء هذه الدراسة لمعرفة التأثير الوقائي و النشـاط المضاد للأكسدة لفول

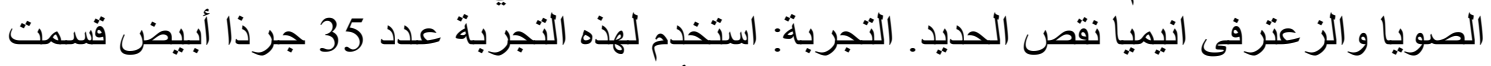

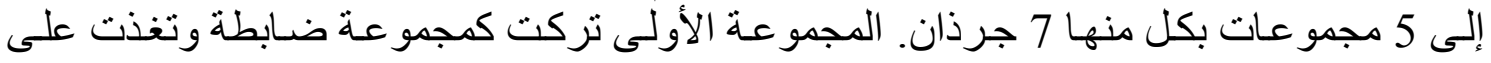

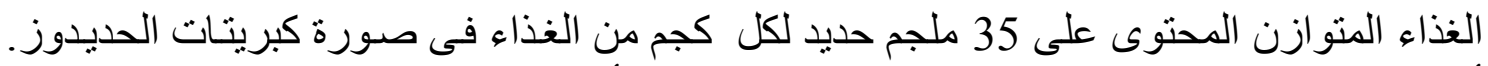

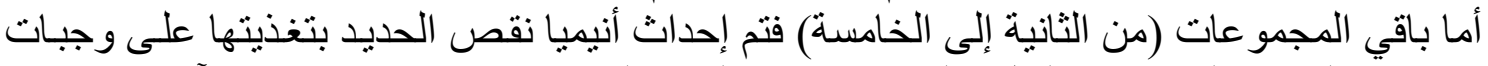

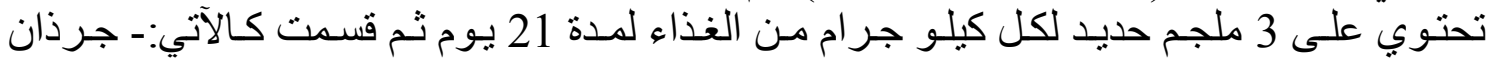

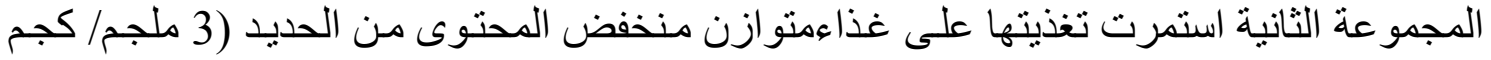

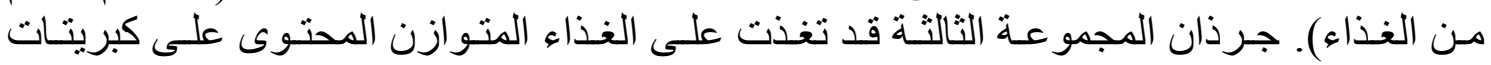

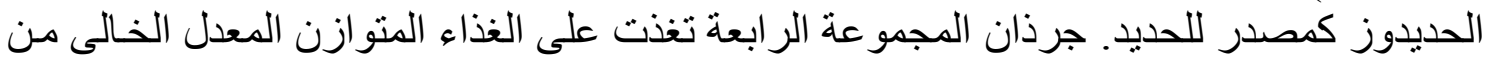

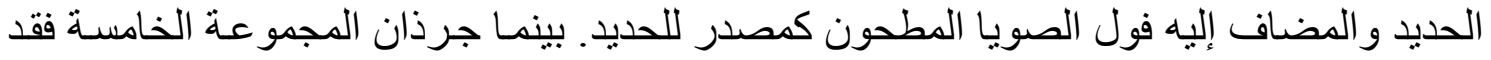

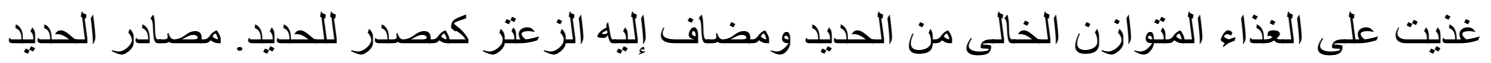

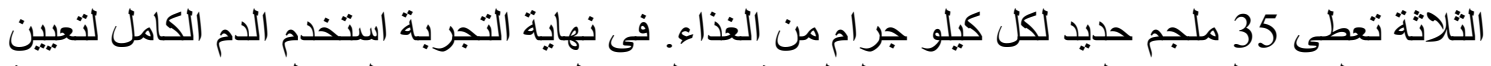

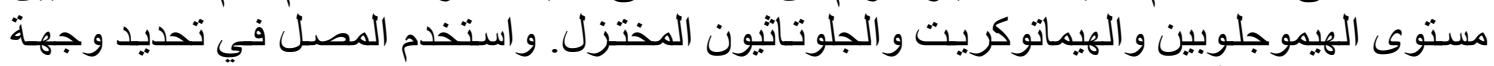

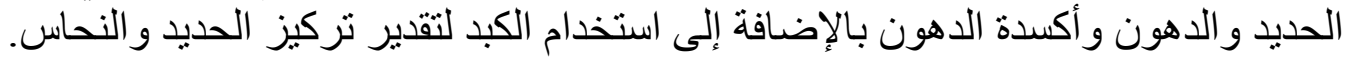

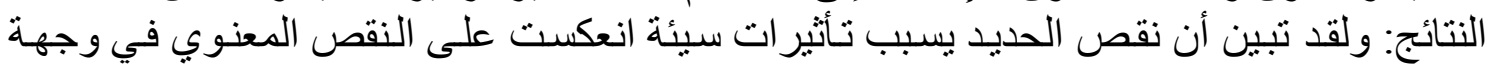

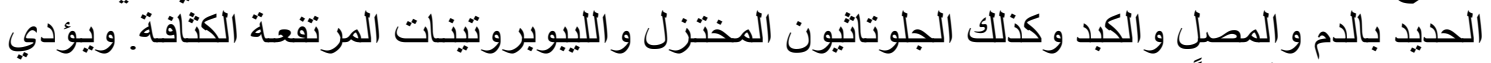

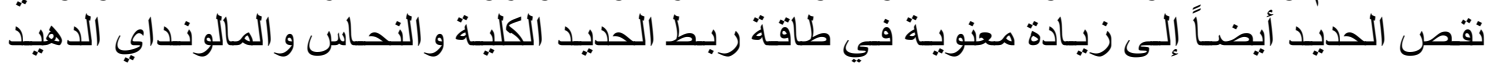

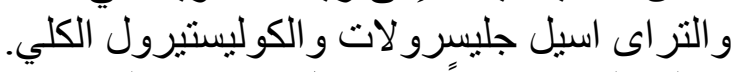

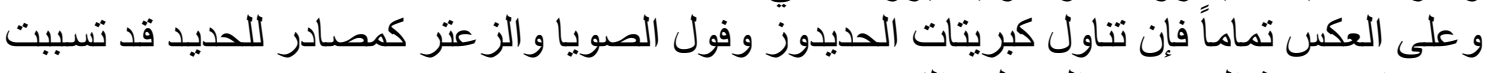

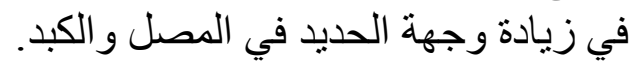

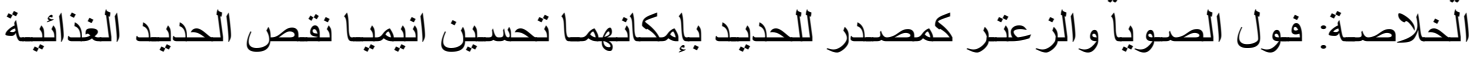

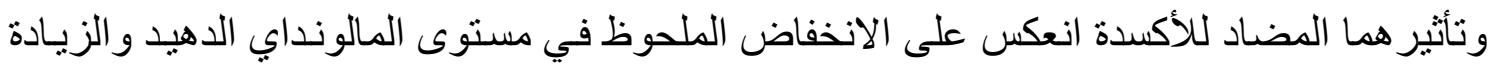
الملحوظة في مستوى الجلوتاثيون المختزل. 